\title{
When Syrian 'Girls' Meet Turkish ‘Boys': Mapping Gendered Stories of Mixed Marriages
}

\section{Selin Akyuz \& Özgün Tursun}

To cite this article: Selin Akyuz \& Özgün Tursun (2019) When Syrian 'Girls' Meet Turkish 'Boys': Mapping Gendered Stories of Mixed Marriages, Middle East Critique, 28:1, 29-49, DOI: 10.1080/19436149.2018.1549215

To link to this article: https://doi.org/10.1080/19436149.2018.1549215

\section{Published online: 07 Feb 2019.}

Submit your article to this journal $\sqsubset$

山ll Article views: 191

Q View related articles $\widetilde{ }$

View Crossmark data \lceil 


\title{
When Syrian 'Girls' Meet Turkish 'Boys': Mapping Gendered Stories of Mixed Marriages
}

\author{
SELIN AKYUZ ${ }^{\mathrm{a}} \&$ ÖZGÜN TURSUN ${ }^{\mathrm{b}}$ \\ ${ }^{a}$ Bilkent University, Ankara, Turkey \\ ${ }^{\mathrm{b}}$ University of Nottingham, UK
}

\begin{abstract}
This article explores the gendered experiences and negotiations of Syrian refugee women throughout forced migration processes and the different strategies during family formation that both Turkish men and Syrian women develop in mixed marriages. Its aim is to unravel fluid gendered experiences that are different from 'reported' stereotypical stories in the media and 'constructed' in the society. By doing so, we argue that the partners' narratives in these mixed marriages enable us to map the intricate ways in which agency is used and echoed gendered experiences of couples in forced migration and family formation. We conducted indepth interviews with eight couples voicing different narratives on how they have negotiated with forms of hierarchies, discourses and how they have refined and transformed their refuge. The incorporation of agency into our analysis unpacked (1) heterogeneity of the spouses and their experiences; (2) potential gendered spaces/discourses to be transformed/refined; and (3) nuances of multifaceted impacts of forced migration. Hence, other than macro studies and tantalizing framings in media, this research offers a dynamic reading of gendered experiences to contribute to the growing literature on Syrian refugees.
\end{abstract}

Key Words: Femininities; Masculinities; Mixed marriages; Syria; Turkey

The only thing that I asked was to buy my wedding dress from Syria. It was very difficult, but we did. Since my father has a passport, he got into Aleppo easily. I went there with my mother. We crossed the border before sunrise. At the end of the day, I found the perfect dress. Then, we waited all night after the sunset. And the other day, before sunrise, we were ready to cross the border. It was very quiet, and there was no gendarmerie at that time. First, I threw my dress over the border fence. Then, a man who lives in a border village in the Turkish side saw us. He helped us cross the border safely and accompanied us to his house until my father came and took us to go to Gaziantep. ${ }^{1}$

Correspondence Address: Selin Akyuz, Bilkent University, İhsan Doğramacı International Advanced Studies Centre, PO Box 06800, Bilkent, Ankara, Turkey. Email: selinak@bilkent.edu.tr

Özgün Tursun, School of Politics and International Relations, University Park, University of Nottingham, NG7 2RD, UK. Email: ozgun.tursun@nottingham.ac.uk

${ }^{1}$ Author Interview with Shayma, Gaziantep, May 29, 2014. 
Since the Syrian regime's violent suppression of democratic protests in 2011, millions of people have been forced to leave their homes and search for shelter in neighboring countries: Jordan, Lebanon, Iraq and Turkey, as well as Egypt and Europe. Policymakers, international aid organizations, NGOs and the media have brought the effects of Syria's civil war to the forefront. The media's representation of Syrian refugees has produced stereotypical images, particularly if viewed through the critical lens of gender: the image of a refugee woman as a victim, a refugee man as a threat and the LGBTI refugee as a non-existent individual. These images have constructed discursive patterns as the reoccurrence of particular representations has reproduced a simplified image of the refugee. Moreover, Katty Alhayek highlights a posteriori effect in her analysis that discusses the media's framing of refugees in Jordan as 'reinforcing Western hegemonic orientalist representation." 2 Such representations shape the discursive ground that both the media and academia have been fed and covertly work as a barrier for transgressing binaries.

As a dominant issue in the media's coverage on Syrian refugees, marriage between Syrian women and local people has been labeled as a trade between the women's father/brother, Turkish middlemen, and Turkish men. ${ }^{3}$ In this way, 'bride trafficking' [gelin ticareti] is the first reoccurring theme in Turkish print and visual media. ${ }^{4}$ Stories of Syrian 'brides' subject to trafficking have reinforced the stereotypical image of the refugee women as being 'desperate' and a 'victim.' These stories have framed Turkish grooms as being 'profiteers' and 'abusive.' 5 The second reoccurring theme is the opposite, even though both are centered upon the trade between Syrian men and Turkish men. Several local media outlets have framed marriages between Syrian refugee women and Turkish men as a 'marriage scheme. ${ }^{6}$ Here, the 'naïve' Turkish man pays a considerable amount of money for a Syrian refugee woman as dowry and marries her; however the 'deceitful' bride then runs away with all the money and assets the 'poor' Turkish man may have had. ${ }^{7}$ Finally, several reports are based on the perceptions of local Turkish women who perceive Syrian women as 'thieves' 'stealing' Turkish men from them. ${ }^{8}$ In this framing, Syrian women are presented as 'more loyal, more obedient;' they do not 'talk back' and are 'well-groomed; and therefore are

\footnotetext{
${ }^{2}$ Katty Alhayek (2014) Double Marginalization: The Invisibility of Syrian Refugee Women's Perspectives in Mainstream Online Activism and Global Media, Feminist Media Studies, 14(4), p. 696.

${ }^{3}$ Uzay Bulut (2016) Turkey: The Business of Refugee Smuggling, Sex Trafficking. Available online at: https://www.gatestoneinstitute.org/7756/turkey-refugees-sex-trafficking, accessed June 25, 2016.

${ }^{4}$ Diken (2014) Suriyelilerle evlilik ticarete döküldü: 'Hemen bir kadın bulabilirim. Birkaç ay evli kalabilirsin' [Marriage with Syrians commodified: 'I can find a woman right away']. Available at: http://www.diken.com.tr/suriyelilerle-evlilik-ticarete-dokuldu-hemen-bir-kadin-bulabilirim-birkac-ay-evlikalabilirsin/, accessed June 25, 2016.

${ }^{5}$ The Guardian (2014) Syria's Refugees: Fears of Abuse Grow as Turkish Men Snap Up Wives. Available at: https://www.theguardian.com/world/2014/sep/08/syrian-refugee-brides-turkish-husbandsmarriage, accessed June 25, 2016.

${ }^{6}$ Haberi Yakala (2015) Suriyeli gelinin evlilik oyunu: Düğ̈̈n sabahı altınları da alıp kaçtı [Marriage scam of Syrian bride: She ran away with the gold on wedding morning]. Available at: http://www. haberiyakala.com/2015-10-02-suriyeli-gelinin-evlilik-oyunu-dugun-sabahi-altinlari-da-alip-kacti-h36363. haber, accessed June 25, 2016.

${ }^{7}$ Milliyet (2016) Damat adayına ikinci Suriyeli gelin darbesi [Second strike groom to be from Syrian bride]. Available at: http://www.milliyet.com.tr/damat-adayina-ikinci-suriyeli-gundem-2199024/, accessed June 25, 2016.

${ }^{8}$ Ümran Avc1 \& Lokman Happani (2014) Neden Suriyeli Gelin? [Why Syrian brides?]. Available at: http://www.haberturk.com/gundem/haber/1003940-neden-suriyeli-gelin, accessed June 25, 2016.
} 
'preferred over Turkish women.' In general, these depictions of Syrian refugee women effectively perpetuate stereotypes that silence the 'voice' of Syrian brides and further ignore how patriarchy operates in forced migration.

The narrative of Shayma (who is married to Mustafa) at the beginning of this article sheds light on this often 'reported' but 'untold' part of mixed marriages. Set against this backdrop, our article aims to give voice to the gendered experiences of Syrian 'girls' and Turkish 'boys' who got married following the onset of civil unrest and proceeded to settle in Gaziantep, a border city in southeast Turkey. We do not assume that 'refugee status in and of itself constitutes a recognizable, generalizable, psychological condition; ${ }^{10}$ and we try to go beyond fixed stereotypes as being a victim/threat or oppressive/profiteer by unpacking the experiences of both partners. It is also worth tracing the different processes during migration and family formation within which men and women have negotiated external demands and gendered hierarchies. Based on these premises, we question how forced migration affected and transformed the gender roles of the agents of mixed marriage ${ }^{11}$ by taking into account multiple refugee experiences that constantly are being renegotiated and the different construction paths of masculinities in the host community.

We argue that forced migration in the context of Syrian civil war occurred in a 'known' path of family migration influenced by the 'traditional' culture in which men-fathers and brothers - make decisions for women. However, the women have found themselves in an 'unknown' and a new social setting, which in turn increases the likelihood of their autonomous decision-making. Women reconstruct 'familiar' roles in an 'unfamiliar' context and the need for a sense of belonging works as a catalyst. Marriage and their family formation work as a stimulus for the reconstruction of their identity by 'becoming' wives of their husbands and brides of their mothers-inlaw, rather than being 'refugees.'

Men also need to legitimize their 'bonding' as a result of society's negative framing of these marriages while they are constructing a new 'home.' In fact, they address gendered power hierarchies in a newly reconstructed masculinized way vis-à-vis their Syrian counterparts. For men, their marriages mark a new venue in which it is possible to maneuver traditional masculine conduct rules by reestablishing new forms of masculinities which in return serve to comply with hegemonic norms. Hence, the partners' narratives in these mixed marriages have the power of revealing the intricate ways in which agency is used during forced migration and mixed family formation.

By unraveling the refugees' micro experiences, this study aims to offer a muchneeded perspective to the existing literature on Syrian refugees that focuses on the macro issues, such as the conditions of the refugees and camps, ${ }^{12}$ policy implementa-

\footnotetext{
${ }^{9}$ Ibid.

${ }^{10}$ Liisa H. Malkki (1995) Purity and Exile: Violence, Memory and National Cosmology among Hutu Refugees in Tanzania (Chicago, IL: University of Chicago Press), p. 510.

${ }^{11}$ Mixed marriage is a term indicating that partners in a marriage may be from different religious and/or ethnic and/or national backgrounds. Aside from transnational marriages that are spatially dispersed and fragmented families, mixed marriages and families, in this article, is used specifically for those in which the wife is a Syrian refugee and the husband is a Turkish citizen. For detailed information, see http://www.gemic.eu/wp-content/uploads/2010/07/WP9-synthesis-report-final.xml, accessed June $30,2016$.

${ }^{12}$ Murat Erdoğan (2017) Türkiye'deki Suriyeliler: Toplumsal Kabul ve Uyum [Syrians in Turkey: Social Acceptance and Cohesion], Hacettepe Üniversitesi Göç ve Siyaset Araştırmaları Merkezi. Available at:
} 
tions and the governance of refugee regimes ${ }^{13}$ as well as the multifaceted impact of displaced Syrians. ${ }^{14}$ This work contributes to the growing literature by incorporating the gender dynamic into the analysis of the multifaceted impacts of forced migration. It is important to recognize their fluid gendered experiences that enable potential spaces for 'agential intervention,' and, 'contribute to make refugees' experiences plural and diverse. ${ }^{15}$ Aside from romanticizing those 'different' experiences, it sheds light on the way those narratives can be heard.

\section{Incorporating Agency Approach: 'Gendered Geographies of Power'}

Several studies on governing migration from a macro perspective call for more effective migration policy with a gender analysis. ${ }^{16}$ However, few recent works have grappled with the micro experiences of migrants. ${ }^{17}$ Unlike works analyzing mixed families with a gender lens, ${ }^{18}$ only a few of these studies has analyzed marriages within refugee communities from a gendered perspective. ${ }^{19}$ Furthermore, recent research has scrutinized the gender dynamic from the perspective of male refugees, deviating from the forced migration literature's tendency to equate gender with women. ${ }^{20}$ Considering that gender is a relational construct between men and women, there is a need to highlight men's experiences of migration to redress historical lacunae on the gendered analysis of migration. As Elena Fiddian-Qasmiyeh argues, men and women are involved differently in migration, generally, and forced migration in

http://www.hugo.hacettepe.edu.tr/HUGO-RAPOR-TurkiyedekiSuriyeliler.pdf, accessed December 24, 2015.

${ }^{13}$ Fulya Memişoğlu \& Aslı Ilgıt (2016) Syrian Refugees in Turkey: Multifaceted Challenges, Diverse Players and Ambiguous Policies, Mediterranean Politics, pp. 1-21.

${ }^{14}$ Nazlı Şenses (2015) Rethinking Migration in the Context of Precarity: The case of Turkey, Critical Sociology, pp. 1-13; Oytun Orhan \& Sabiha Şenyücel Gündoğar (2015) Effects of the Syrian Refugees on Turkey, Ortadoğu Stratejik Araştırmalar Merkezi. Available at: http://tesev.org.tr/wp-content/ uploads/2015/11/Effects_Of_The_Syrian_Refugees_On_Turkey.pdf, accessed June 28, 2016.

${ }^{15}$ Nando Sigona (2014) The Politics of Refugee Voices: Representations, Narratives, and Memories, in Elena Fiddian-Qasmiyeh, Gil Loescher, Katy Long \& Nando Sigona (eds) The Oxford Handbook of Refugee and Forced Migrations Studies (Oxford: Oxford University Press), pp. 370-378.

${ }^{16}$ Erin K. Baines (2004) Vulnerable Bodies: Gender, the UN and the Global Refugee Crisis (Aldershot: Ashgate Publishing); Bhupinder S. Chimni (2009) The Birth of a 'Discipline': From Refugee to Forced Migration Studies, Refugee Studies, 22(1), pp. 11-29; Jane Freedman (2010) Protecting Women Asylum Seekers and Refugees: From International Norms to National Protection, International Migration, 48(1), pp. 175-198; Jennifer Hydman (2010) Introduction: The Feminist Politics of Refugee Migration, Gender, Place and Culture, A Journal of Feminist Geography, 17(4), pp. 453-459.

${ }^{17}$ Lucy Williams (2006) Social Networks of Refugees in the United Kingdom: Tradition, Tactics and New Community Spaces, Journal of Ethnic and Migration Studies, 32(5), pp. 865-879; Kathy Burrell (2008) Male and Female Polishness in Post-war Leicester: Gender and its Intersections in a Refugee Community, in: Louise Ryan \& Wendy Webster (eds) Gendering Migration: Masculinity, Femininity, and Ethnicity in Post-war Britain, pp. 71-87 (Aldershot: Ashgate Publishing); and L. Williams (2010) Global Marriage: Cross-Border Marriage Migration in Global Context (London: Palgrave Macmillan).

${ }^{18}$ Rosemary Breger \& Rosanna Hill (eds) (1998) Cross-cultural Marriages: Identity and Choice (Oxford: Berg); Deborah Bryceson \& Ulla Vuorela (eds) (2002) The Transnational Family: New European Frontiers and Global Networks (Oxford: Berg); L. Williams, Global Marriage.

${ }^{19}$ Oivind Fuglerud (1999) Life on the Outside: The Tami Diaspora and Long Distance Nationalism (London: Pluto Press); L. Williams, Social Networks of Refugees in the United Kingdom; Hung C. Thai (2008) For Better or For Worse: Vietnamese International Marriages in the New Global Economy (New Brunswick, NJ: Rutgers University Press).

${ }^{20}$ L. Ryan \& W. Webster (eds) (2008) Gendering Migration, p. x. 
particular. $^{21}$ The binary depictions of women as victims and men as perpetrators need to be transcended ${ }^{22}$ by incorporating an agency approach that would help us to move beyond those binaries in migration studies and echo different experiences. Thus, it is critical to define the parameters of the analytical map used in this research.

Agency is a useful concept in differentiating the individual's 'autonomous' position and his/her 'capacity' and/or 'ability' to act/decide/initiate within mixed marriages. ${ }^{23}$ According to Lucy Williams, 'debates about the nature of agency coalesce around the balance between individuals autonomous, political or socio-economic positions and the ability to act within power structures such as family, community, national and international institutions. ${ }^{24}$ As Deniz Kandiyoti argues, in the Middle East, the classical belt of patriarchy, not only patriarchal culture and Islam but also local realities and political agendas construct gender(ed) relations. ${ }^{25}$ Such patriarchal culture, which stretches from North Africa across the Middle East covering both Turkey and Syria, refers to women who are subservient to men and less likely to express overt resistance. ${ }^{26}$ We do not oversimplify patriarchy as simply the rule of fathers rather we take it as a multifaceted network of relations with respect to distribution of power. Deniz Kandiyoti also suggests that the study of women's agency and gender relations must be analyzed to explore multiple forms of oppression. According to her, intersecting institutional and cultural constraints at the local, national and international levels always circumscribe contestation and resistance. ${ }^{27}$ Hence, the agency of men and women may take different forms in different places under varying circumstances and times.

Against this backdrop, an agency approach is needed to map gendered stories of mixed marriages, offering a means of discerning different strategies, negotiations and tactics within power structures that position themselves as 'refugees,' 'victims,' 'threats' or any other stereotyped categories for both sexes. This approach enables us to analyze how individuals facing similar circumstances may act and assists in exploring the assumed vulnerability of migrants. We argue that victimization silences refugees and their fluid gendered experiences. In this framework, our study tries to go beyond the rooted categorization of 'war brides' of the Syrian civil war and reads their 'familiar' gendered relations of family formation in an 'unfamiliar' situation.

In conjunction with the concept of agency, in this specific work, we rely on Patricia Pessar and Sarah Mahler's concept of 'gendered geographies of power,' which offers a

${ }^{21}$ E. Fiddian-Qasmiyeh (2014) Gender and Forced Migration, p. 399.

${ }^{22}$ Caroline O. N. Moser \& Fiona C. Clark (2001) Victims, Perpetrators or Actors? Gender, Armed Conflict and Political Violence (London and New York: Zed Books).

${ }^{23}$ Ken Plummer (1995) Telling Sexual Stories: Power, Change and Social Worlds (London: Routledge); Laura M. Ahearn (2001) Language and Agency, Annual Review of Anthropology, 30, pp. 109-137; Paul Hoggett (2001) Agency, Rationality and Social Policy, Journal of Social Policy, 30(1), pp. 37-56; and L. Williams, Social Networks of Refugees in the United Kingdom: Tradition, Tactics and New Community Spaces.

${ }^{24}$ L. Williams (2006) Global Marriage: Cross-Border Marriage Migration in Global Context, p. 37.

${ }^{25}$ Deniz Kandiyoti (1988) Bargaining with Patriarchy, Gender and Society, 2(3), pp. 274-290; and idem (1998) The Impact of Migration on Turkish Rural Women: Four Emergent Patterns, Gender and Society, 12, pp. 146-167.

${ }^{26}$ D. Kandiyoti (1999) Rethinking the Patriarchal Bargain, in Cecile Jackson \& Ruth Pearson (eds) Feminist Visions of Development (London: Routledge) p. 139; and Faedah M. Totah (2013) The Memory Keeper: Gender, Nation, and Remembering in Syria, Journal of Middle East Women's Studies, 9(1), pp. 1-29.

${ }^{27}$ Ibid. 
sense of dynamism between the four main building blocks for understanding how migrants live, work and socialize, which are namely, geographic, social location, agency and imagination. ${ }^{28}$ Geographies refer to 'multiple spatial and social scales,' while the 'social location' designates multiple and intersecting hierarchies of gender, class and ethnicity within which women and men are positioned/disciplined. ${ }^{29}$ The third building block deals with how women and men exert agency 'as initiators, refiners, transformers,' and the final one considers the importance of imagination and cognitive processes. Our research analyzes the narratives of refugees' and their partners in different 'spaces' with an emphasis on how they are negotiated with intersecting hierarchies and how they initiate, refine and transform their refuge with the help of imagination and planning.

\section{Methodological Framework: Situating the Research and Ourselves}

The transformation of civil unrest into a civil war deepened the humanitarian crisis in Syria. As a result, according to UNHCR data, 5.6 million Syrians fled to neighboring countries. $^{30}$ Turkey, with its $800 \mathrm{~km}$-long border, became one of the most important destinations for Syrians. As of September 2018, Turkey hosts more than 3,500,000 Syrian refugees, and is the largest host country for Syrian refugees in the region. ${ }^{31}$ The vast majority of Syrian refugees live outside the camps, mainly in cities close to the Syrian border (Gaziantep, Kilis, Şanlıurfa, Hatay).

By conducting our field research in the Turkish border city of Gaziantep, we had the advantage of witnessing the Syrian refugee influx while working at a local university between September 2012 and September 2014. Gaziantep tended to be the first destination of choice for Syrian refugees. ${ }^{32}$ By 2015, the city was populated overwhelmingly by refugees, coming second after Istanbul. ${ }^{33}$ As of September 2018, the city hosts four camps with a total of 3,718 persons and 406,183 registered Syrians are living elsewhere in the city. ${ }^{34}$ Our ethnographic research coincided with local protests against Syrians in Gaziantep and thereafter in other border cities hosting Syrians. Especially, during summer 2014, a mass protest ${ }^{35}$ caused Syrian refugees to hide their identities and refuse to be 'interviewed.' As this has affected our research, we deem it important to discuss our position as scholars.

Our position eased access into local networks, while also hindering our encounters with refugees. Firstly, our affiliation with a well-known university in the city paved the way for our research. It facilitated our encounters with mediators and relatives of

\footnotetext{
${ }^{28}$ Sarah J. Mahler \& Patricia R. Pessar (2001) Gendered Geographies of Power: Analyzing Gender Across Transnational Spaces, Identities, 7(4), pp. 441-459.

${ }^{29}$ Ibid, p. 445.

${ }^{30} \mathrm{http}: / /$ data.unhcr.org/syrianrefugees/regional.php, accessed October 20, 2018.

${ }^{31}$ See United Nations High Commissioner for Refugees (UNHCR) (2018) Syrian Regional Refugee Response, Inter-agency Information Sharing Portal. Available at: https://data2.unhcr.org/en/situations/ syria, accessed October 20, 2018.

${ }^{32}$ O. Orhan \& Ș. Gündoğar (2015) Suriyeli Sı̆̆ınmacıların Türkiye'ye Etkileri [Syrian refugees' impact on Turkey].

33 Ibid.

${ }^{34}$ http://www.goc.gov.tr/icerik6/gecici-koruma_363_378_4713_icerik, accessed October 12, 2018.

${ }^{35}$ Thomas Seibert (2014) Syrian Refugees face backlash in Turkey. Available at: http://www.thenational. ae/world/turkey/syrian-refugees-face-backlash-in-turkey, accessed June 25, 2016.
} 
Syrian families. Moreover, our urban birthplaces provided an icebreaker with our informants and 'home' cities. Selin, female researcher, born and raised in western Turkey, was perceived as a 'guest.' Özgün, male researcher, from Gaziantep was greeted as a local and usually was questioned about his local kinship ties and then acknowledged as 'one of us.' Furthermore, we were sensitive to the advice of Maria Jaschok and Shui Jingjun, who emphasized the importance of researchers locating their positionalities within a feminist methodological terrain:

Researching a 'foreign culture' and research in one's own culture have their unique merits and problems. The social place occupied by foreign researchers as well as the distance between them and their research subjects sensitizes the researcher when conducting investigations into an alien culture. ${ }^{36}$

In parallel with their analysis, as Turkish researchers familiar with their culture but trained in Western-oriented theoretical frameworks, we experienced a multiplicity of subjectivities with gendered, religious, cultural and social connotations. Özgün smoothed potential social barriers between the researchers and interviewees. On the other hand, Selin's position as a 'relative foreigner' doubled the sensitivity of informants toward her as a 'guest,' prompting 'Turkish hospitality,' which served to narrow the divide between researcher and interviewee. From a position of potential disadvantage, she was afforded an advantage when interviewing women informants sharing similar gender experiences. Hence, our 'outsider within' ${ }^{, 37}$ status harbored different nuances: being from Gaziantep or not, from which we could comprehend Syria as a foreign society in a local context, Gaziantep, within our informants' unfamiliar context of forced migration. In effect, these ambiguities helped us to avoid fixed hypotheses and our 'continual exchange and dialogue' with our informants decreased 'the distance between ourselves and our informants. ${ }^{38}$ In this framework, the importance of situating ourselves is double-fold. First, our positions not only loosened the barriers between us and the respondents, but also being aware of it widened our 'potential' myopic lens, which could have been affected by a pre-given hegemonic representation. Second, in line with Nando Sigona's remark on the nature of interview as a 'mutually situated and mediated encounter, ${ }^{39}$ situating ourselves eliminated the risks of analyzing the data by 'normalizing' it.

According to data published by the Turkish Statistical Institute (TUIK), 3,569 Syrian brides were 'legally' married to Turkish spouses, while 241 Syrian grooms were married to Turkish brides at the time this research was conducted. ${ }^{40}$ Relying on qualitative research methods, we conducted 16 in-depth interviews with eight families consisting of Syrian brides and Turkish grooms. In this framework, we do not claim that our research sample is representative of all Syrian-Turkish mixed marriages. However, as shown in Table 1, the sample of respondents in this research varied in

\footnotetext{
${ }^{36}$ Maria Jaschok \& Shui Jingjun (2000) Outsider Within: Speaking to Excursions across Cultures, Feminist Theory, 1(1), pp. 42-43.

${ }^{37}$ Ibid.

${ }^{38}$ Ibid, p. 43.

${ }^{39}$ N. Sigona (2014) The Politics of Refugee Voices: Representations, Narratives, and Memories, p. 376.

${ }^{40} \mathrm{This}$ data is collected from Turkish Statistical Institute, Gaziantep upon authors' request.
} 
Table 1. Demographic information of the interviewed couples

\begin{tabular}{llll}
\hline Names & \multicolumn{1}{c}{ Ethnicity } & \multicolumn{1}{c}{ Education } & \multicolumn{1}{c}{ Occupation } \\
\hline Shayma (26) Mustafa (30) & Arab/Turkish & Middle S./High S. & Housewife/Barber \\
Kamar (20) Ibrahim (28) & Arab/Turkish & Primary S./High S. & Housewife/Workman \\
Rima (20) Ersin (21) & Arab/Turkish & Primary S./High S. & Housewife/Pharmacy Tec. \\
Mais (17) Yavuz (28) & Turkoman/Turkish & Primary S./High S. & Housewife/Sales assistant \\
Lely (21) Emre (27) & Arab/Turkish & College/High S. & Housewife/Sales assistant \\
Asya (30) Mahmut (50) & Arab/Turkish & Primary S./High S. & Housewife/Shopkeeper \\
Nour (26) Faruk (30) & Arab/Turkish & College/High S. & Housewife/Shopkeeper \\
Amira (22) Mehmet (25) & Kurdish/Kurdish & High S./Middle S. & Housewife/Barber \\
& & & \\
\hline
\end{tabular}

terms of ethnicity, age, education and occupation. This non-uniformity of the sample has enriched the scope of the research.

The mixed families were identified by a snowballing technique through local networks. We reached five additional couples, yet they preferred not to be interviewed for security reasons. This became more frequent with increasing tension about Syrians in Turkey. Some refugees were hesitant about revealing their identities and recounting their stories. Moreover, it is important to note that couples with a Syrian groom and a Turkish bride generally refused to talk to us. This may have arisen because the brides in these marriages were widowers and older than the grooms, which is uncommon in Turkish culture.

Finally, contrary to what often was insinuated in the media, polygynous marriages were not common among our interviewees. We encountered only one example of polygyny, yet we are well aware that our sample does not represent the full spectrum of mixed marriage patterns. Polygyny is not strictly illegal in Turkey. ${ }^{41}$ Men who want to have two wives get married with imam nikahl, which is a religious wedding ceremony performed by an imam [religious leader]. However, it is important to note that religious weddings are important for Syrians, and drawing on interviews, we can argue that a majority of Syrian refugee families demanded an imam nikahı for their daughters due to bureaucratic difficulties that make it nearly impossible for them, as non-Turkish citizens, to obtain required Syrian legal documents necessary to marry a Turkish citizen under legal civil law.

\section{Reconstructing 'Familiar' Roles in an 'Unfamiliar' Context}

When the war broke out, we did not immediately leave the country. We carried on working for nine months. But then, my father said that we should leave. I did not want to leave my city but my father told us to do so, so we left. ${ }^{42}$

\footnotetext{
${ }^{41}$ The Constitutional Court recently repealed the penalties for having a religious marriage before having a legal marriage. This decision stirred debates on polygyny in Turkey. For details see Hürriyet (2015) Top Court Ruling on Religious Marriages Sparks Debate in Turkey. Available at: http://www. hurriyetdailynews.com/top-court-ruling-on-religious-marriages-sparks-debate-in-turkey. aspx?pageID $=238 \& n I D=83167 \&$ NewsCatID=341, accessed June 30, 2016.

42 Author Interview with Shayma, Gaziantep, May 29, 2014.
} 
The beginning of Shayma's story reflects the male-dominated sociocultural order and family migration pattern. Social and political roles in Syria are aligned with ascribed patriarchal gendered roles. ${ }^{43}$ The custodianship of tradition tends to be assigned to women and the domestic sphere ${ }^{44}$ while men are the family decision-makers and determine women's boundaries. As Suad Joseph argues, '(...) policies, laws and institutions have produced gender inequalities that reinforce the patriarchal character of the society, i.e., its privileging of men over women. ${ }^{45}$ Furthermore, these hierarchical gender relations should not be interpreted as 'natural' or 'self-evident', instead as 'context-specific social, political and cultural constructions of gender. ${ }^{46}$ Given the 'forced' political atmosphere, individuals are seeking security and 'are at least temporarily unable to control key dimensions of their existence. ${ }^{47}$ This alternatively shadows the decision-maker's ability to act within power structures. However, gendered hierarchies bringing 'the interaction and negotiation between structure and agency' to the fore reveal how hierarchical gender structures will prevail $^{48}$ in this circumstance.

In a similar vein, Nour's story illustrates how gendered hierarchies have affected her 'ability to act.' It had been 16 months since her family fled. Before the war, she was studying business administration. She explained: 'I did not want to leave my home, but we had to. It was unsafe. My brothers did not want to leave either. And they continued to stay there with their families. They are still in Syria. We came here, to Gaziantep with my sisters and parents. ${ }^{49}$ While her brothers 'managed' to convince their parents, Nour's father considered it unsafe for Nour and her sisters to remain in Syria. Kamar's story is similar. When the war broke out, the family left their village and moved to Aleppo but as conditions worsened, they moved to Gaziantep. She explained, 'My aunties were here in Gaziantep. When I first came here I liked it a lot. It was similar to Aleppo. But then, after a while my parents became unhappy here. My father could not find a job, and they returned to our country. But I stayed here with my auntie. ${ }^{50}$ Kamar seemed content about her parents' decision to leave Syria and move to Gaziantep and wished to remain in Gaziantep when her parents decided to leave. She made efforts to identify cultural similarities between Syria and Turkey, providing herself a sense of 'home.' During our interview, she kept referring to similar customs between the two cultures and cities, such as common ways of greeting and similar cuisine. In this framework, these behaviors can be considered 'an attempt of the construction of the feeling of closeness in everyday life and dialogue, an attempt of sharing the experiences and problems in spite of the different sociocultural contexts. ${ }^{51}$ The meaning of home as discussed in the

${ }^{43}$ Ross Thompson (2000) The Legacy of Early Attachments, Child Development, 71(1), pp. 145-152; Suad Joseph (2000) Gendering Citizenship in the Middle East, Gender and Citizenship in the Middle East, S. Joseph (ed.) (Syracuse, NY: Syracuse University Press) pp. 3-30; and F. M. Totah (2013) The Memory Keeper: Gender, Nation, and Remembering in Syria, Journal of Middle East Women's Studies, 9(1), pp. 1-29.

${ }^{44}$ F. M. Totah (2013) The Memory Keeper, p. 3.

${ }^{45}$ S. Joseph (2000) Gendering Citizenship, p. 3.

${ }^{46}$ Doreen Indra (1999) Room of One's Own: Engendering Forced Migration Knowledge and Practice, in: D. Indra (ed.) Engendering forced Migration Theory and Practice (Oxford: Berghahn Books), p. 8.

${ }^{47}$ Ibid, p. 18.

${ }^{48}$ L. Williams (2006) Global Marriage, p. 37.

${ }^{49}$ Authors' Interview with Nour, Gaziantep, July 21, 2014.

${ }^{50}$ Ibid.

${ }^{51}$ Jana Rosker (1996) The Methodology of Intercultural Research, Ljubljana, Faculty of Arts (in Slovene) p. 53, and cited in Natalija Vrecer (2000) Human Costs of Temporary Refugee Protection: The Case of Slovenia, in: Adrianne Rubeli \& Nina Vucenik (eds) A Captured Moment in Time: IWM Junior Visiting Fellows Conferences, Vol. X, p. 6 (Vienna: IWM). 
forced migration literature may take different forms as a domestic residence, source of comfort, feeling of safety, kinship ties, origins etc. ${ }^{52}$ In this vein, making Gaziantep home associates with an intertwined conceptualization of a geographical space and a feeling of safety fueled by familiarity.

Rima also highlighted how she loved that Gaziantep is similar to Aleppo where she had lived before the war. She had stayed with some relatives in Gaziantep who also had fled. Three families were staying together in a house owned by her mother-in-law. She mentioned 'even though everything was difficult at first,' she was positive about Gaziantep: 'Maybe we did not have any other choice, but I really like it here. We have some relatives, and my father found a job thanks to them. ${ }^{53}$ Her story marks how the 'familiarity' of living with relatives and having some social circles facilitated their resettlement. Apparently, in line with the literature, refugees un/consciously create familiar places of practices after experiencing life changes. As the literature suggests, marriage is one of the ways to construct new refuges. ${ }^{54}$ Al-Ali argues that 'an analysis of changing family dynamics helps to shed light on how gender relations and links to home country are shaped with respect to the circumstances of flight from a war-torn country, becoming a refugee and trying to create and maintain everyday life in receiving country. ${ }^{55}$ While trying to maintain a new life, Lely told us, "Camp is not a house. It is a tent. My parents are still living in the camp. I have a new home now. ${ }^{56}$ For her, she and her new husband have constructed a new home with new social attachments.

We were living in the camp. My husband-to-be was working in the camp. He asked a friend of our family to tell us his intent to marry me. I asked her what kind of a person must he be? Does he drink alcohol? Is he pious? (...) I was hesitant about marriage, as I wanted to go back to Syria after war ends. I wanted to continue my education. Then my mother, who heard very good things about him, insisted that I marry him. Then, I saw him for 10 minutes in the camp. I looked into his eyes and said yes. It was sudden but nice... The coming week, we had the engagement ceremony. ${ }^{57}$

Lely's hesitation about marrying and her intention of returning to Syria ended after her family and friends persuaded her otherwise. In her narrative, marrying a Turk gave her a sense of belonging: "now we are a family in Turkey. ${ }^{, 58}$ As Lucy Williams argues 'marriage, as a rite of passage, is particularly important for refugees who seek a sense of belonging in exile and, for some, marriage is an essential means of establishing oneself as a full member of the community. ${ }^{59}$ Lely added: 'Our wedding was so good. It

\footnotetext{
${ }^{52}$ Priya Kissoon (2006) Home/lessness as an Indicator of Integration: Interviewing Refugees about the Meaning of Home and Accommodation, in: Bogusia Temple \& Rhetta Moran (eds) Doing Research with Refugees: Issues and Guidelines, pp. 75-96 (Bristol: The Policy Press).

53 Author Interview with Rima, Gaziantep, June 12, 2014.

${ }^{54}$ L. Williams (2006) Global Marriage, p. 142.

${ }^{55}$ Nadje Al-Ali (2002) Loss of Status or New Opportunities? Gender Relations and Transnational Ties among Bosnian Refugees, in D. Bryceson \& U. Vuorela (eds) The Transnational Family: New European Frontiers and Global Networks (Oxford: Berg Publishing), p. 98.

${ }^{56}$ Author Interview with Lely, Gaziantep, July 21, 2014.

${ }^{57}$ Ibid.

${ }^{58}$ Ibid.

${ }^{59}$ L. Williams (2006) Global Marriage, p. 142.
} 
was the best day of my life. ... It was also very funny. The translator was present the whole time. It was like a meeting of UN. Everybody was there speaking different languages but celebrating the same event. Emre got special permission, so that his relatives could enter the camp. My father wanted to do everything as if we were in Syria. So, the groom came to our tent to take me as his bride. I have never visited the camp again. ${ }^{60}$ In effect, Lely constructed this ceremony as a clear rupture between her previous experiences as a refugee living in the camp and her new life as 'his bride.' Through marriage, she transformed her status into the wife of Emre, instead of a Syrian refugee.

Nour's story marks another 'agential intervention.' She is married to Faruk, a photographer running his own shop. She said, 'It was love at first sight. He was my brother's friend. One day, I decided to send him a flower bouquet. I wrote a note saying, "Would you like to meet me?" Then, we started dating. After getting to know him, I told him that I wanted to grow old with him. ${ }^{61}$ Nour was confident about herself and her decision to marry Faruk. She explained to her family that she wanted to get married: 'I was ready for that. I loved him. That's all I wanted. ${ }^{62}$ Nour's agency as initiator during their marriage was very pronounced and it illustrates that the geometry of relational power is defined by who controls the production, content and direction of the decision-making flow. ${ }^{63}$ While the vulnerable situation of being a refugee may limit her range of choices, her way of exerting agency as initiator and her autonomous decision-makings have underpinned her efforts of starting a new life.

Marriage preparations, according to our interviewees, were a matter of careful planning and anticipation. All the interviewed brides told us about shopping before the ceremony, the henna night ${ }^{64}$ and the event. For instance, Mais told us; 'I went shopping with my mother-in-law and my mother. They bought everything I asked for. The dress for my henna night was beautiful. ${ }^{65}$ Similarly, Kamar's memories of the henna night and the wedding ceremony reflected her enjoyment and satisfaction:

We had the religious ceremony first. All my relatives and friends came afterwards to celebrate with us. I also wanted a gender segregated henna night. It has always been a dream for me. It was one of the best nights in my life. ${ }^{66}$

Mais's and Kamar's stories about their henna night and their demand for a 'proper' celebration according to 'approved' customs can be considered as a way 'to demonstrate one's position in the community and thus confirm that a proper order has been restored after the chaos and ignominy of forced migration. ${ }^{, 67}$ In addition to ensuring that their customs and traditions matched their own, their stories marked some transgression of space and conventional practices.

\footnotetext{
${ }^{60}$ Author Interview with Lely.

${ }^{61}$ Author Interview with Nour, Gaziantep, July 21, 2014.

${ }^{62}$ Ibid.

${ }^{63}$ S. Pessar \& P. R. Mahler (2003) Transnational Migration: Bringing Gender In, The International Migration Review, 37(3), p. 817.

${ }^{64}$ Henna night is a traditional ceremony for the bride-to-be.

${ }^{65}$ Author Interview with Mais, Gaziantep, July 17, 2014.

${ }^{66}$ Author Interview with Kamar, Gaziantep, May 29, 2014.

${ }^{67}$ L. Williams (2006) Global Marriage, p. 154.
} 
Syrian brides have evinced new practices that challenge the 'stereotyped fixation on their victimhood. ${ }^{68}$ Trajectories of migration create channels for women to reconstruct their gender roles, but, we argue that, the term 'empowerment' falls short of nuances. Gina Buijs maps a more dynamic process that she calls 'remaking of self." ${ }^{69}$ Similarly, Ali Akbar Mahdi, in his important work on changes in gender roles among Iranian migrant families in the United States highlights how migration enables the creation of new modes of gendered relationships in the family environment. ${ }^{70}$ Hence, the stories of brides, analyzed through a gender lens, reveal more when seen as a 'creative process.'

Upon the importance of taking stories as 'creative process,' Lely's attempts to alter the customs, especially within the boundaries of the Turkish family, mark another significant process of negotiation.

I learned after the birth of my first child that it is customary to give gold bracelets immediately following childbirth. But my in-laws did not do so. Now for the second baby, I will ask double. ${ }^{71}$

Although Lely was laughing as she relayed this story, she was certain how she wanted to 'alter' the practice. The interview was conducted in the presence of her husband, who was sitting in the corner of the room. She deliberately repeated louder: 'I want my bracelets!' and whispered to the interviewer 'I want to keep them for the future of my girls.' In open resistance to stereotyped accounts of Syrian brides as dependent and vulnerable, Lely's narrative exemplifies the twist on 'to construct a notion of self that is in dialogue, negotiation ... those emanating from a traditionmodernity dichotomy. ${ }^{, 72}$ Receiving valuable gifts are part of Turkish traditions when giving birth. Lely's intervention with Turkish traditions can be acknowledged as a sign of transgressing it by simply and 'unconventionally' voicing her opinion for what she already should have received. In line with 'patriarchal bargain,' she explicitly negotiated to acquire new powers. ${ }^{73}$ Furthermore, it is a way of controlling the content and direction of the issue while, for Turkish family formation the rules of conduct already have been set and strictly applied. Mothers-in-law are generally the main actors who control the whole process starting from choosing the 'right' spouse for their son. Therefore, while the power is ascribed to senior women in the family, brides strive to gain autonomy. ${ }^{74}$ The power interplay between bride and mother-in-law is described as ' $[\ldots]$ the cyclical nature of woman's power in the household and their anticipation of inheriting the authority of senior woman encourages a specific kind of identification

\footnotetext{
${ }^{68}$ Umut Erel (2002) Reconceptualizing Motherhood: Experiences of Migrant Women from Turkey Living in Germany, in: D. Bryceson \& U. Vuorela (eds) The Transnational Family, p. 129.

${ }^{69}$ Gina Buijs (1993) Migrant Women: Crossing Boundaries and Changing Identities (Oxford: Berg), p. 17.

${ }^{70}$ Ali Akbar Mahdi (1999) Trading Places: Changes in Gender Roles within the Iranian Immigrant Family, Middle East Critique, 8(15), pp. 51-75.

${ }^{71}$ Author Interview with Lely.

${ }^{72}$ U. Erel (2002) Reconceptualizing Motherhood, p. 129.

${ }^{73}$ D. Kandiyoti (1988) Bargaining with Patriarchy, p. 274.

${ }^{74}$ Nükhet Sirman (1995) Friend of Foe? Forging Alliances with Other Women in a Village of Western Turkey, in: Şirin Tekeli (ed.) Women in Modern Turkish Society: A Reader (London: Zed Books), pp. 199-218.
} 
with the system of hierarchy. ${ }^{, 75}$ Shayma acknowledged her mother-in-law's authority: 'She is our everything. I love her so much. I hope my child will be like her. After my daughter's birth, we will have two Ayşes - the mother-in-law's name - in the same house. ${ }^{76}$ Her remark signifies the importance of 'gendered micro politics of negotiation, cooperation and contestation. ${ }^{, 77}$ She cooperates with the conventional norms, and while she is not in open resistance to gendered hierarchies, this well tunes with their remake of identity.

Burrell argues that 'forced migration highlights the significance of gender either as a site of rupture or as an anchoring space. ${ }^{, 78}$ For Syrian women, their narratives reveal how fluid their experiences during the remake of their gender identity. As every setting requires different strategies, we must not assume that gendered roles are one-dimensional or fixed to deep-rooted hierarchies. Narratives of Syrian brides manifest their different ways of exerting agency. While Shayma cooperates with the conventional and wants to name her child after her mother-in-law, Lely unconventionally ask two bracelets when she gives birth to her second child. Both use different ways of initiation, with the same goal of conforming to their current life. Hence, Syrian 'refugees' transform into brides not only by constructing 'safe' home but also by conforming to the conventional gendered hierarchies. To locate a gendered map of their family formation, narratives of Turkish grooms will uncover the other side that highlights the relationality of gender.

\section{Legitimizing 'Bonding' and Constructing a New 'Home'}

According to Umut Erel, 'The stereotype of the Turkish family as an embodiment of tradition can be seen to exert ambivalent responses of longing and envy for stability as well as disdain for a presumably archaic and sexist institution. ${ }^{79}$ Erel's argument encapsulates the binaries within the Turkish family, as tradition in the sense of the patriarchal gender order marks continuity, and any alternative deviation from 'the Turkish family' can be labeled as transgressive. Mixed families can be considered as an alternative family formation in Turkey, and they generate ambivalent emotions and reactions. Additionally, the media's negative framing of Syrian women also emboldens Turkish grooms to find 'commonness' with their brides. This explains why Turkish grooms related detailed narratives about their gendered negotiations and also how they legitimized their marriages beyond 'love' or 'bonding.' Men's narratives reveal their masculinized negotiations and coping mechanisms within a mixed marriage.

For example, according to Ersin, who married Rima: 'Society has a negative image of Syrians, so it is important for me to know if she is a pious Muslim or not. ${ }^{, 80}$ Even though his family welcomed his decision to marry a 'Syrian,' he needed to legitimize his choice, i.e., that his bride was a devout Muslim. Mustafa, who was aware that

\footnotetext{
${ }^{75}$ D. Kandiyoti (1988) Bargaining with Patriarchy, p. 279.

${ }^{76}$ Author Interview with Shayma.

${ }^{77}$ Gillian Hart (1995) Gender and Household Dynamics: Recent Theories and Other Implications, in: Muhammad G. Quibra, Critical Issues in Asian Development (Hong Kong: Oxford University Press) p. 61, and cited in D. Kandiyoti, Rethinking the Patriarchal Bargain, p. 140.

${ }^{78}$ K. Burrell (2008) Male and Female Polishness in Post-war Leicester, p. 71.

${ }^{79}$ U. Erel (2002) Reconceptualizing Motherhood, p. 129.

${ }^{80}$ Author Interview with Ersin, Gaziantep, June 12, 2014.
} 
religion facilitates an attachment between his wife and mother, reveals another important strategy commonly used by male interviewees.

My mother liked Shayma a lot, she is very beautiful, well-mannered and a pious Muslim. There is racism against Arabs in Turkey. People do not understand the difference between Syrians and Arabs. They see Arabs as traitors. Even my father-in-law accepts that Arabs stabbed Ottomans in the back. ${ }^{81}$

With a sense of confidence, after getting his mother's approval, which is necessary for the family formation, he readily 'discriminates' between Syrians and Arabs while trying to legitimize his decision. In addition, on the other side, his wife and her family also needed 'divine' approval.

Before our marriage, they tested me to understand if I knew Arabic, and I answered that I did not. They asked if I could read the Qur'an, and I said yes. They wanted me to read a passage from the Qur'an, and when I did, they were surprised. $^{82}$

For Ibrahim, who married Kamar, finding an ethnic tie was important. After describing his wife's good manners and how happy he is, Ibrahim said:

We have no problems, because they are descendants of Turks. During the Ottoman times, Gaziantep was a small town of the Aleppo region. Later they drew a borderline between Turkey and Syria. Some of us stayed here, others stayed on the other side. They are all like us. ${ }^{83}$

His definition of space and the remaking of space describe marriage as an attachment between 'similar' individuals coming from the same descendant, hence, normalizing their marriage. Like Ibrahim, Murat followed the pattern of ethnic similarity. When we asked Murat about the reactions of friends and family members to his decision to marry a Syrian woman, he cited being Kurdish as a justification: 'Amira is not Syrian. She is Kurdish just like us. ${ }^{84}$ Insistence on ethnic background is also quite apparent in Yavuz's responses. He stated that his 'wife is not a Syrian, in fact a Turk.' He had no hesitations about Mais and her family because she is ethnically from Turkish nomad lineage, and her ancestors had migrated a century ago to Syria from Turkey. ${ }^{85}$

Mahmut's story hints at different legitimizing strategies, as he was the only groom among our interviewees who was a part of a polygynous marriage. Unlike other polygynous couples who refused to be interviewed, Mahmut and Asya were eager to talk to us. Mahmut owns a big furniture shop and told their story from the very beginning:

\footnotetext{
${ }^{81}$ Author Interview with Mustafa, Gaziantep, May 29, 2014.

82 Ibid.

${ }^{83}$ Author Interview with Ibrahim, Gaziantep, May 29, 2014.

84 Ibid.

${ }^{85}$ Author Interview with Yavuz, Gaziantep, July 17, 2014.
} 
My employees are Syrians, and I was joking about getting married again. One day they brought her [Asya] to the store. I asked them to leave [because] I needed to talk to my wife and kids first. I asked them to leave for a few days to let us decide. That night I told my wife that a woman wanted to marry me and asked for her opinion. My 'big' wife said, 'While I am away visiting our kids, you are lonely. So good luck with it, you have my blessing.' I told my employee that I was ready and willing to marry Asya. She was living in the refugee camp with her family. My 'big wife' took Asya shopping and bought everything she needed as a bride. $^{86}$

After their imam nikahı ceremony, Mahmut and his two wives started living in the same house, but this did not last long. According to Mahmut, 'Asya was jealous of the first wife and asked me to rent a separate place for her. I bought a new house and new furniture for my first wife and took her to that new flat.' Mahmut spoke highly of Syrian women,

They say if you want a true wife you should marry a Circassian woman, but they pale in comparison with Syrian women. I just learned that there is a good world out there. What a relief! If I came to the world ten times, I would marry an Arab girl ten times! ${ }^{87}$

Mahmut delightedly mentioned how this marriage changed his thinking, and how he persuaded his 'college graduate son to marry a Syrian girl.' He shared his feelings with his son,

Since I am content with this [Asya], I told him if you want a peaceful household, I suggest Syrians. I feel like a real man again.

She is always listening to religious TV channels. Before, it was always Turkish pop music channels ... When I came home tired, I was supposed to listen to what my big wife and kids were listening to. Now I am very happy. This is the type of house that I want. My new wife takes care of me in every aspect. ${ }^{88}$

Mahmut had a strategy by receiving the blessing of his 'big wife,' which eased his decision, and his changing perception of Syrian women helped him to 'normalize' his marriage preferences. Persuading his sons was another means to legitimize a mixed marriage, with his emphatic statement that Syrians are the 'best' option in the 'marriage market.' The way that he exercises agency is allowing him to step away from culturally accepted forms of marriages by reproducing normative masculine ideals. However, Asya has her own strategy as she had been living in a tent with eight relatives in poverty when her hand was offered to Mahmut, a local businessman. According to the narrative, Asya had no or little voice in this decision. Yet, as soon as she marries Mahmut, she started asserting her agency when she asked for a separate place as she did not want to live with Mahmut's first wife. Furthermore, she gave birth to a child even though Mahmut refused; he consented when Asya insisted. Rather than

\footnotetext{
${ }^{86}$ Author Interview with Mahmut, Gaziantep, June 14, 2014.

${ }^{87}$ Ibid.

88 Ibid.
} 
living as a refugee with her extended family in a tent, she transformed herself into a wife and mother in her own household.

'Learning Turkish' or 'learning Arabic' is another issue for mixed couples. According to Rosemary Breger and Rosanna Hill,

In a mixed marriage, the partners do not share the same mother tongue, the language in which they decide to communicate at home can be symbolic of the extent to which each partner is prepared to forego her or his cultural background and incorporate new elements. ${ }^{89}$

For instance, Mustafa stated, 'I don't think I am going to learn Arabic, Shayma is learning Turkish, and we can communicate in Turkish.' On the other hand, arrangements differed for Ersin, 'When we visit her family, I cannot communicate with them. Rima is learning Turkish. She is doing very well. I am looking for an Arabic course. I want to learn as soon as possible to make our life easier for her.' Similarly, Faruk started to learn Arabic from Nour, 'My teacher is Nour. She is great.' Occasionally, they visit Nour's family and Faruk added, 'They speak a little Turkish, I speak a little Arabic, so we can understand each other. But it could be better. ${ }^{90}$ Grooms have different ways of exerting agency in 'language issue.' Unlike Mustafa who decided not to learn Arabic as long as they could 'communicate,' Ersin and Faruk would try to learn to communicate better. Their efforts reflect an unexpected move by Turkish grooms who typically do not show any interest in the well-being of the household other than bread-winning.

Similarly, in the traditional Turkish gendered division of labor, men only 'help' their wives with certain female household activities. However, Georgata Nazarska and Marko Hajdinjak found that in both mixed and transnational families in Bulgaria, Greece and Turkey ' $(. .$.$) the traditional gendered labor division at home has changed$ significantly. Many such men say that they evenly share the household work with their wives and they do not divide it into "male" and "female.",91 In our research, Mustafa said: "Shayma tries to serve me all the time, even when she is pregnant. I told her that life here in Turkey is different, life is to be shared...' While he emphasized the importance of sharing, he also positioned Turkish family life as different from Syrian. Similarly, his wife also places Mustafa as 'not like Syrian men.' In parallel with Nazarska and Hajdinjak's argument on mixed families in Turkey where a 'non-traditional gender division of domestic labor seems to be common,' in the accounts of both spouses, they are 'different' and also 'better. ${ }^{92}$ Mustafa explained: 'My wife came to me and asked me "if I am carrying a baby girl, will you be angry with me?", He thought this reflected how Syrian men treat their women. If Syrian women fail to bear a male child at once, Syrian men marry again. Mustafa further remarked that he had seen how Syrian men treat their women, 'When Shayma and I got engaged, her uncle visited us. Once we asked where his wife was, and he replied that she was at

\footnotetext{
${ }^{89}$ R. Breger \& R. Hill (eds) (1998) Cross-cultural Marriages, p. 21.

${ }^{90}$ Author Interviews with Mustafa, Ersin and Faruk.

${ }^{91}$ Georgata Nazarska \& Marko Hasdinjak (2010) Invisible Engines of Change and Self-sacrificing Tradition-breakers: Mixed and Transnational families in Bulgaria, Greece and Turkey. Sofia: International Center for Minority Studies and Intercultural Relations. Available at: http://www.gemic. eu/wp-content/uploads/2010/07/WP9-synthesis-report-final.pdf, accessed December 24, 2015, p. 20. 
the hospital in labor. We were surprised and asked him why he was here and not at the hospital with his wife. He said "I told her I don't want a daughter; if she is pregnant with a daughter, I am going to send her back to her family. I have better things to do than wait for her in the hospital." For me, it is not like this,' said Mustafa. 'I told Shayma "Would you even be able to put a price on a single hair of our daughter's?" I only want you and the baby to be healthy, I will be thankful to Allah for that.' His view well accentuates intersecting hierarchies of gender and nationalities with reference to their construction of masculinities. While situating himself in a higher position than his Syrian counterpart, Mustafa as the better man, reproduces his masculinities vis-à-vis him. The grooms whom we interviewed were the 'subordinated' ones in Gaziantep's marriage market as they lacked the social and economic capital to marry Turkish women; so they marry 'beautiful' and 'young' Syrian woman. Specifically, men are considered as evde kalmış [spinster], a derogatory word denoting an unmarried man/woman who lacks local compatibility expectations. Therefore, by 'belittling' Syrian men they reproduce their masculinities to become part of hegemonic masculine norms over time. Ironically, they maneuver from the conventional norm of being a tough husband and reproduce a new, emotionally caring husband who, in the end, complies with hegemonic masculinities.

The narratives manifest how changes 'can catalyze capabilities and promote claims for autonomy and personal agency. ${ }^{93}$ In this line, mixed marriage has redefined Syrian women's lives during their search for bonding and a refuge, while Turkish men have negotiated various demands imposed on them, such as the changes required of them and also the gendered power hierarchies that they encounter. These grooms reconstruct their masculinities and their gender roles serve as 'scripts defining rules of interactions in the context of marriage. ${ }^{, 94}$ In line with Jeroen Cuvelier's argument, our respondents mix 'practices from various origins, by giving personal interpretations to the ideals they identify with and by changing their attitudes toward these ideals according to the situations they are in and the interests they are pursuing at particular moments in their lives. ${ }^{95}$ Hence, we argue that they remake their masculinities by changing the accepted norms of being a caring husband and become 'better' than Syrian husbands, even though the way they position themselves vis-à-vis 'other' is in compliance with the construction of hegemonic masculinities.

\section{Conclusion}

This research reveals how forced migration has affected, transformed and/or challenged gender roles within hierarchical power structures. Several common themes emerged in our study of mixed marriages. First, mixed marriage of Syrian brides and Turkish grooms offered a fertile analytical ground to discuss the different ways of agential intervention. The marriage provided the partners a venue to remake their identity construction. Other than following the known path of gendered rules within the family, the partners experienced a process of negotiation, transformation and inversion.

\footnotetext{
93 Ibid. p. 40.

${ }^{94}$ Mahdi (1999) Trading Places, p. 52.

95 Jeroen Cuvelier (2014) Work and Masculinity in Katanga's Artisanal Mines, Africa Spectrum, 49(2), p. 15 .
} 
Their non-normative marriage, a mixed marriage in a post forced migration setting despite the negative image portrayed in the media and public discourses, enabled the bride and the groom to contrast with the normative notions of feminine and masculine behaviors.

Second, our findings demonstrated that Syrian refugee women married to Turkish men are not 'homogenous' as framed in the media. A myopic lens on Syrian woman as a victim falls short of revealing the multifaceted dynamics. We argue that marriage worked as a rupture from their previous gendered hierarchies for Syrian women. Even though our respondents showed little or no agency for their migration from Syria to Turkey, they were active decision-makers of their marriage processes.

Third, by marrying Turkish men, Syrian women fulfill their desire to conform to their new life in Turkey. All respondents had been living in tough conditions either in camps or outside camps. In both conditions, they were living in a small place (tent/ flat) with at least 6-7 people from their families with no prospects of returning to Syria. Some brides acknowledged this situation by comparing their situation in the camp and their social setting after marrying a Turkish man. Other brides did not want to be a burden to their families. In both cases, the desire to conform to living in Turkey appeared to be an important incentive to accept marrying a Turkish man.

Fourth, the decision to marry a Turkish man also was connected to the need to have a 'sense of belonging.' Based on our data, we argue that marriage offers a 'new' beginning for Syrian refugee women. Ongoing and increasing turmoil in Syria wipe away hopes for 'returning back home.' Syrian women openly acknowledged this, and they all wanted to live the rest of their lives in Turkey. In other words, Syrian refugee women perceived marriage as a process that transforms their social status from being 'refugee' to 'wife' or 'bride.' While this transformation involves different negotiations and strategies, shared ethnicity, language and religion of forced migrants and the local population eases this process.

Fifth, gendered negotiations of the Syrian women best unfold during the early stage of their marriages. We argue that Syrian women negotiate with the 'new gendered hierarchies of power' in two ways in order to open space and find a safe haven for themselves in their new refuge. When encountering new gendered cultural contexts, some embraced their existing gender roles in the household by doing domestic chores, i.e., cooking, taking care of the whole family. By anchoring to their traditional gender roles, they feel valuable and secure in their new households. However, others adopted the existing gendered hierarchies they encountered. For example, by accepting the seniority of a mother-in-law, they also reproduced the identification of the system of hierarchy within the household. Even by challenging the traditions, i.e., asking for gold bracelets, they demanded to acquire new powers that would serve their future interests.

Finally, even though Turkish grooms were not the active agents of forced migration, their gender roles have been affected by their marriages to Syrian women. The reoccurring theme of justification of marriage was important to all the Turkish grooms whom we have interviewed. Not surprisingly, a main motivation behind this need for justification related to the media representations of the Syrian refugees at large. While justifying their decision to marry Syrian women, our respondents tried to disassociate their brides from the overall Syrian population by highlighting their similarities with themselves. Interestingly, all our male respondents implicitly or explicitly agreed with media representations of Syrian refugees but not for their brides. The way they 
legitimized their decision to marry a non-Turk revealed not only the importance of ethnic background, religion, and language but also gendered hierarchies in the remaking. Male respondents situated themselves and their masculinity by comparing themselves with their Syrian counterparts, defining themselves as 'better men.' In the framework of the construction of masculinities, these husbands are enacting a hegemonic masculinity. As Raeweyn Connell argues, what is 'hegemonic' regulates masculinities. ${ }^{96}$ Hence, being a better Turkish husband marks such a hierarchical classification and reveals how these grooms situate themselves as better even though previously they were 'subordinated' as 'evde kalmış' [spinster] men in the local Turkish marriage market. Mixed marriage worked as a rite of passage into hegemonic masculinities for Turkish grooms as they moved from being 'subordinated men' to 'better husbands.'

In summary, this research offers a snapshot of mixed marriages between Turks and Syrians. Our study helps us to map the motivations, as well as to offer a better understanding of the underlying gendered hierarchies and strategies of Syrian women and Turkish men. As an initial step to understanding how family formation in a post-forced migration setting informs feminine and masculine identities, this research documents different strategies for mixed marriages while also demonstrating their intertwining in a gendered process.

\section{References}

Ahearn, L. M. (2001) Language and Agency, Annual Review of Anthropology, 30, pp. 109-137.

Al-Ali, N. (2002) Loss of Status or New Opportunities? Gender Relations and Transnational Ties among Bosnian Refugees, in: Bryceson, D. \& Vuorela, U. (eds) The Transnational Family: New European Frontiers and Global Networks, pp. 83-102 (Oxford: Berg Publishing).

Alhayek, K. (2014) Double Marginalization: The Invisibility of Syrian Refugee Women's Perspectives in Mainstream Online Activism and Global Media, Feminist Media Studies, 14(4), pp. 696-700.

Avc1, U. \& Happani, L.. (2014) Neden Suriyeli Gelin? [Why Syrian brides?]. Available at: http://www. haberturk.com/gundem/haber/1003940-neden-suriyeli-gelin, accessed June 25, 2016.

Baines, E. K. (2004) Vulnerable Bodies: Gender, the UN and the Global Refugee Crisis (Surrey: Ashgate Publishing).

Breger, R. \& Hill, R. (eds) (1998) Cross-cultural Marriages: Identity and Choice (Oxford: Berg).

Bryceson, D. \& Vuorela, U. (eds) (2002) The Transnational Family: New European Frontiers and Global Networks (Oxford: Berg).

Buijs, G. (1993) Introduction, in: Buijs, G. (ed.) Migrant Women: Crossing Boundaries and Changing Identities, pp. 1-20 (Oxford: Berg).

Bulut U. (2016) Turkey: The Business of Refugee Smuggling, Sex Trafficking. Available at: https://www. gatestoneinstitute.org/7756/turkey-refugees-sex-trafficking, accessed June 25, 2016.

Burrell, K. (2008) Male and Female Polishness in Post-war Leicester: Gender and its Intersections in a Refugee Community, in: Ryan, L. \& Webster, W. (eds) Gendering Migration: Masculinity, Femininity, and Ethnicity in Post-war Britain, pp. 71-87 (Aldershot: Ashgate Publishing).

Chimni, B. S. (2009) The Birth of a 'Discipline': From Refugee to Forced Migration Studies, Refugee Studies, 22(1), pp. 11-29.

Connell, R. (1995) Masculinities (Berkeley, CA: University of California Press).

Cuvelier, J. (2014) Work and Masculinity in Katanga's Artisanal Mines, Africa Spectrum, 49(2), pp. 3-26.

Diken (2014) Suriyelilerle evlilik ticarete döküldü: 'Hemen bir kadın bulabilirim. Birkaç ay evli kalabilirsin' [Marriage with Syrians commodified: 'I can find a woman right away']. Available at: http://www.diken. com.tr/suriyelilerle-evlilik-ticarete-dokuldu-hemen-bir-kadin-bulabilirim-birkac-ay-evli-kalabilirsin/, accessed June 25, 2016.

\footnotetext{
${ }^{96}$ Raewyn Connell (1995) Masculinities (Berkeley, CA: University of California Press).
} 
Erdoğan, M. (2014) Türkiye'deki Suriyeliler: Toplumsal Kabul ve Uyum [Syrians in Turkey: Social Acceptance and Cohesion], Hacettepe Üniversitesi Göç ve Siyaset Araştırmaları Merkezi. Available at: http://www.hugo.hacettepe.edu.tr/HUGO-RAPOR-TurkiyedekiSuriyeliler.pdf, accessed December 24, 2015.

Erel, U. (2002) Reconceptualizing Motherhood: Experiences of Migrant Women from Turkey Living in Germany, in: Bryceson, D. \& Vuorela, U. (eds) The Transnational Family: New European Frontiers and Global Networks, pp. 127-146 (Oxford: Berg).

Fiddian-Qasmiyeh, E. (2014) Gender and Forced Migration, in: Fiddian-Qasmiyeh, E., Loescher, G., Long, K. \& Sigona, N. (eds) The Oxford Handbook of Refugee and Forced Migrations Studies, pp. 395-408 (Oxford: Oxford University Press).

Freedman, J. (2010) Protecting Women Asylum Seekers and Refugees: From International Norms to National Protection, International Migration, 48(1), pp. 175-198.

Fuglerud, O. (1999) Life on the Outside: The Tami Diaspora and Long Distance Nationalism (London: Pluto Press)

The Guardian (2014) Syria's Refugees: Fears of Abuse Grow as Turkish Men Snap Up Wives. Available at: https://www.theguardian.com/world/2014/sep/08/syrian-refugee-brides-turkish-husbands-marriage, accessed June 25, 2016.

Haberi Yakala (2015) Suriyeli gelinin evlilik oyunu: Dügü̈n sabahı altınları da alıp kaçtı [Marriage scam of Syrian bride: She ran away with the gold on wedding morning]. Available at: http://www.haberiyakala. com/2015-10-02-suriyeli-gelinin-evlilik-oyunu-dugun-sabahi-altinlari-da-alip-kacti-h36363.haber, accessed June 25, 2016.

Hart, G. (1995) Gender and Household Dynamics: Recent Theories and Other Implications, in: Quibra, M. G., Critical Issues in Asian Development (Hong Kong: Oxford University Press) p. 61, and cited in Kandiyoti, D. (1999) Rethinking the Patriarchal Bargain, p. 140.

Hoggett, P. (2001) Agency, Rationality and Social Policy, Journal of Social Policy, 30(1), pp. 37-56.

Hürriyet (2015) Top Court Ruling on Religious Marriages Sparks Debate in Turkey. Available at: http:// www.hurriyetdailynews.com/top-court-ruling-on-religious-marriages-sparks-debate-in-turkey.aspx?page $\mathrm{ID}=238 \& \mathrm{nID}=83167 \&$ NewsCatID=341, accessed June 30, 2016.

Hydman, J. (2010) Introduction: The Feminist Politics of Refugee Migration, Gender, Place and Culture, $A$ Journal of Feminist Geography, 17(4), pp. 453-459.

Indra, D. (1999) Room of One's Own: Engendering Forced Migration Knowledge and Practice, in: Indra, D. (ed.) Engendering Forced Migration Theory and Practice, pp. 1-21 (Oxford: Berghahn Books).

Jaschok, M. \& Jingjun, S. (2000) Outsider Within: Speaking to Excursions across Cultures, Feminist Theory, 1(1), pp. 33-58.

Joseph, S. (2000), Gendering Citizenship in the Middle East, in: Joseph, S. (ed.) Gender and Citizenship in the Middle East, pp. 3-30 (Syracuse, NY: Syracuse University Press).

Kandiyoti, D. (1988) Bargaining with Patriarchy, Gender and Society, 2(3), pp. 274-290.

Kandiyoti, D. (1999) Rethinking the Patriarchal Bargain, in: Jackson, C. \& Pearson, R. (eds) Feminist Visions of Development, pp. 135-153 (London: Routledge)

Kissoon, P. (2006) Home/lessness as an indicator of integration: Interviewing Refugees about the Meaning of Home and Accommodation, in: Temple, B. \& Moran, R. (eds) Doing Research with Refugees: Issues and Guidelines, pp. 75-96 (Bristol: The Policy Press).

Mahdi, A. A. (1999) Trading Places: Changes in Gender Roles within the Iranian Immigrant Family, Middle East Critique, 8(15), pp. 51-75.

Mahler, S. J. \& Pessar, P. R. (2001) Gendered Geographies of Power: Analyzing Gender Across Transnational Spaces, Identities, 7(4), pp. 441-459.

Malkki, L. H. (1995) Purity and Exile: Violence, Memory, and National Cosmology Among Hutu Refugees in Tanzania (Chicago: The University of Chicago Press).

Memişoğlu, F. \& Ilgıt, A. (2017) Syrian Refugees in Turkey: Multifaceted Challenges, Diverse Players and Ambiguous Policies, Mediterranean Politics, 22(3), pp. 1-21.

Milliyet (2016) Damat adayına ikinci Suriyeli gelin darbesi [Second strike groom to be from Syrian bride]. Available at: http://www.milliyet.com.tr/damat-adayina-ikinci-suriyeli-gundem-2199024/, accessed June $25,2016$.

Moser, C. O. N \& Clark, F. C. (2001) Victims, Perpetrators or Actors? Gender, Armed Conflict and Political Violence (London and New York: Zed Books).

Nazarska, G. \& Hasdinjak, M. (2010) Invisible Engines of Change and Self-sacrificing Tradition-breakers: Mixed and Transnational families in Bulgaria, Greece and Turkey. Sofia: International Center for 
Minority Studies and Intercultural Relations. Available online at: http://www.gemic.eu/wp-content/ uploads/2010/07/WP9-synthesis-report-final.pdf, accessed December 24, 2015.

Orhan, O. \& Şenyücel, Gündoğar, S. (2015) Effects of the Syrian Refugees on Turkey. Ortadoğu Stratejik Araştırmalar Merkezi. Available online at: http://tesev.org.tr/wp-content/uploads/2015/11/Effects_Of_ The_Syrian_Refugees_On_Turkey.pdf, accessed June 28, 2016.

Pessar, P. R. \& Mahler, S. J. (2003) Transnational Migration: Bringing Gender In, The International Migration Review, 37(3), pp. 812-846.

Plummer, K. (1995) Telling Sexual Stories: Power, Change and Social Worlds (London: Routledge).

Rosker, J. (1996) The Methodology of Intercultural Research, Ljubljana, Faculty of Arts [in Slovene] p. 53, and cited in Vrecer, N. (2000) Human Costs of Temporary Refugee Protection: The Case of Slovenia, in: Rubeli, A. \& Vucenik, N. (eds) A Captured Moment in Time: IWM Junior Visiting Fellows Conferences Vol. X, p. 6 (Vienna: IWM).

Ryan, L. \& Webster, W. (eds) (2008) Gendering Migration: Masculinity, Femininity, and Ethnicity in Postwar Britain (Aldershot: Ashgate Publishing).

Seibert, T. (2014) Syrian Refugees face backlash in Turkey. Available at: http://www.thenational.ae/world/ turkey/syrian-refugees-face-backlash-in-turkey, accessed June 25, 2016.

Sigona, N. (2014) The Politics of Refugee Voices: Representations, Narratives, and Memories, in: FiddianQasmiyeh, E., Loescher, G., Long, K. \& Sigona, N. (eds) The Oxford Handbook of Refugee and Forced Migrations Studies, pp. 369-382 (Oxford: Oxford University Press).

Sirman, N. (1995) Friend of Foe? Forging Alliances with Other Women in a Village of Western Turkey, in: Tekeli, S.. (ed.) Women in Modern Turkish Society: A Reader (London: Zed Books).

Şenses, N. (2015) Rethinking Migration in the Context of Precarity: The Case of Turkey, Critical Sociology, 42(8), pp. 1-13.

Thai, H. C. (2008) For Better or For Worse: Vietnamese International Marriages in the New Global Economy (New Jersey: Rutgers University Press).

Thompson, R. A. (2000) The Legacy of Early Attachments, Child Development, 71(1), pp. 145-152

Totah, F. M. (2013) The Memory Keeper: Gender, Nation, and Remembering in Syria, Journal of Middle East Women's Studies, 9(1), pp. 1-29.

Vrecer, N. (2000) Human Costs of Temporary Refugee Protection: The Case of Slovenia, in: Rubeli, A. \& Vucenik, N. (eds) A Captured Moment in Time: IWM Junior Visiting Fellows Conferences, vol. X, pp. 1-21 (Vienna: IWM).

Williams, L. (2006) Social Networks of Refugees in the United Kingdom: Tradition, Tactics and New Community Spaces, Journal of Ethnic and Migration Studies, 32(5), pp. 865-879.

Williams, L. (2010) Global Marriage: Cross-Border Marriage Migration in Global Context (London: Palgrave Macmillan). 